
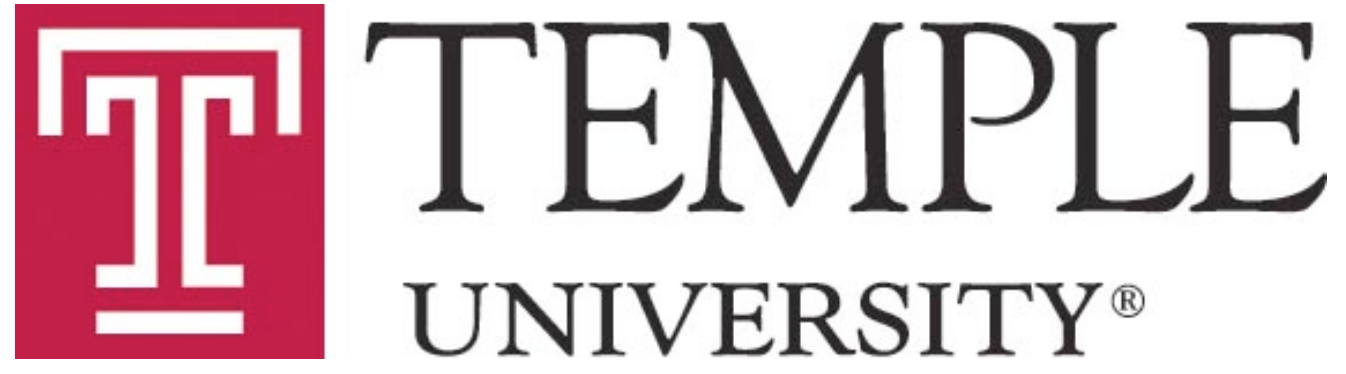

\title{
Leaving school in an economic downturn and self-esteem across early and middle adulthood
}

\author{
by \\ Johanna Catherine Maclean \\ Department of Economics \\ Temple University \\ catherine.maclean@temple.edu \\ Terrence D. Hill \\ Department of Sociology \\ The University of Utah \\ terrence.hill@soc.utah.edu \\ Department of Economics \\ DETU Working Paper 15-05 \\ January 2015
}

1301 Cecil B. Moore Avenue, Philadelphia, PA 19122

http://www.cla.temple.edu/economics/faculty/detu-working-paper-series/ 


\title{
Leaving school in an economic downturn and self-esteem across early and middle adulthood
}

\author{
Johanna Catherine Maclean, Ph.D., ${ }^{\mathrm{a}, *}$ \\ Terrence D. Hill, Ph.D. ${ }^{\mathrm{b}}$
}

\begin{abstract}
In this study we test whether leaving school in an economic downturn impacts self-esteem. Self-esteem is an important dimension of non-cognitive skill that economists have recently begun to examine. Previous work documents that leaving school in a downturn persistently depresses career outcomes, and career success is an important determinant of self-esteem. We model responses to the Rosenberg Self-esteem Scale as a function of the state unemployment rate at school-leaving. We address the potential endogeneity of time and location of schoolleaving with instrumental variables. Our results suggest that leaving school in an economic downturn lowers self-esteem men but effects do not emerge until middle adulthood, and are particularly strong for white and high skill men.
\end{abstract}

Keywords: self-esteem; non-cognitive skills; school-leaving; macroeconomic fluctuations.

JEL classification: I1; I12; J2

Disclaimer: This research was conducted with restricted access to Bureau of Labor Statistics (BLS) data. The views expressed here do not necessarily reflect the views of the BLS.

${ }^{a}$ Department of Economics, Temple University, Ritter Hall Annex 869, 1301 Cecil B. Moore Avenue, Philadelphia, PA 19122; Telephone: 215-204-0560; catherine.maclean@temple.edu.

${ }^{\mathrm{b}}$ Associate Professor, The University of Utah, Department of Sociology, 380 S 1530 E, Room 301, Social \& Behavioral Sciences, Salt Lake City UT, Tel: 801-581-6153, E-mail: terrence.hill@soc.utah.edu.

*Corresponding author. 


\section{Introduction}

In this study, we test whether leaving school during an economic downturn can persistently undermine self-esteem. Self-esteem is an important dimension of non-cognitive skill that economists have recently begun to examine (Heckman et al. 2006). Our work is based on a growing line of research showing persistent negative career (Oyer 2006, 2008; Genda et al. 2010; Kahn 2010; Oreopoulos et al. 2012), marriage (Hershbein 2012; Maclean et al. 2013), and health outcomes (Maclean 2013; Maclean 2014) for individuals who leave school in an economic downturn. Because sociological research shows that labor market success, stabile marriages, and good health support positive self-esteem (Rosenberg \& Pearlin 1978; Haney 2007; Waite et al. 2009), leaving school in an economic downturn may erode self-esteem by increasing the probability of poor outcomes in labor and marriage markets, and poor health.

Self-esteem refers to the positive or negative evaluation of the self as an object (Rosenberg 1965; Rosenberg 1981; Owens \& King 2001; Mruk 2006). It is indicated by individual perceptions of worthiness (e.g., "I have a number of good qualities.") and competence (e.g., "I am able to do things as well as most other people.”). According to Rosenberg (Rosenberg 1965), self-esteem “...is not present at birth but arises out of social experience and interaction; it both incorporates and is influenced by the individual's location in the social structure; it is formed within institutional systems, such as the family, school, economy, church; it is constructed from the materials of the culture; it is affected by immediate social and environmental contexts (p 593)." Sociologists and psychologists have studied self-esteem for over a century (e.g., Cooley (1902), James (1893), and (Rosenberg 1965)), but economists have only recently begun to incorporate this important concept (and other non-cognitive traits such as personality traits) into their research (Heckman \& Rubinstein 2001; Heckman et al. 2006; Mueller \& Plug 2006; Cunha \& Heckman 2008; Cunha et al. 2010; Almlund et al. 2011; 
Heckman \& Kautz 2012). Nevertheless, because sociologists and psychologists have largely ignored the impact of broader economic conditions when studying the social distribution of selfesteem, it is especially important for economists to address these forces.

Conceptually, self-esteem is unique and important because it is associated with a broad range of outcomes related to health and well-being, academic achievement, employment, civic engagement, and deviant behavior (Rosenberg 1981; Markowitz 2001; Mruk 2006; Yang 2006). In general, those who possess higher levels of self-esteem have better outcomes across these domains than those with lower self-esteem. Moreover, because these social outcomes have implications for social welfare understanding determinants of self-esteem is warranted.

We draw data from the National Longitudinal Survey of Youth 1979 Cohort (NLSY79) and model self-esteem, as measured by the Rosenberg Self-esteem Score (Rosenberg 1965), at various points across the adult life course as a function of the state unemployment rate at schoolleaving. To this end we exploit variation generated by volatility in the United States economy between 1976 and 1987 to identify self-esteem effects. We address the potential endogeneity of both the time and location of school-leaving with instrumental variables. Specifically, we follow the literature on the persistent effects of leaving school in an economic downturn and utilize instruments based on birth year, state of residence at age 14, and early life educational expectations (Oyer 2006; Kahn 2010; Oreopoulos et al. 2012; Maclean 2013; Maclean 2014).

Our results suggest that economic conditions experienced at school-leaving do persistently affect self-esteem. Individuals who left school in an economic downturn have lower self-esteem than their counterparts who left school under stronger economic conditions. These findings do not emerge until middle age, however. This pattern of results is consistent with the hypothesis that cumulative exposure to negative experiences in labor and marriage markets gradually undermines the self-concept. In accordance with much of the previous work on the 
career, marriage, and health effects of leaving school in an economic downturn our self-esteem findings are stronger for men than women, particularly white and high skill men. The results are robust to the use of instrumental variables and robustness checks. As such, they contribute to the broader literature on the persistent effects of leaving school in an economic downturn.

\section{Conceptual framework}

We first review sociological theories of self-esteem. We then discuss how the economic literature on the effects of leaving school in an economic downturn can augment these theories.

\subsection{Sociological theories of self-esteem}

There are three general social psychological principles to help explain the formation and development of self-esteem. These general social psychological principles include reflected appraisals, social comparisons, and self-attributions. Each of these principles contributes to our understanding of the processes through which broader economic conditions might be internalized and integrated into the self-concept.

The principle of reflected appraisals suggests that self-esteem is determined by our perceptions of how we think others see us (Cooley 1902; Mead 1934; Rosenberg \& Pearlin 1978; Rosenberg 1981; Gecas 1982). When people perceive that they are valued and respected, self-esteem will tend to be high. When people perceive that they are devalued and disrespected, self-esteem will tend to be low. Our perceptions of how we think others see us are largely dependent upon socialization processes and our understanding of broader cultural values. Because one's socioeconomic status is imbued with social meaning, it represents an important criteria for self-judgment and the development of the self-concept. According to the principle of reflected appraisals, individuals who leave school during an economic downturn are likely to experience negative reflective appraisals due to limited opportunities for occupational and status attainment. This may be especially true when those conditions are experienced during the transition from school to work, when initial attachment to the labor market is generally formed.

The principle of social comparisons suggests that self-esteem is determined by what we 
learn about ourselves when we compare ourselves to others (Festinger 1954; Rosenberg \& Pearlin 1978; Rosenberg 1981; Gecas 1982; Wood 1989). When we contrast ourselves to others, our self-evaluations are by definition relative to a selected reference group or standard in the social environment. Social comparisons are ubiquitous in life. They involve explicit evaluations (e.g., performance evaluations), salient comparisons (e.g., coworkers), and countless informal comparisons (e.g., comparisons mediated by social interaction and the media). According to the principle of social comparisons, individuals who leave school during an economic downturn are likely to exhibit lower levels of self-esteem because they tend to compare unfavorably with salient reference groups (e.g., individuals with similar credentials) who left school during more prosperous economic conditions.

The principle of self-attributions suggests that self-esteem is determined by perceptions of personal effectiveness and competence in achieving desired outcomes in life (Bandura 1978; Rosenberg \& Pearlin 1978; Rosenberg 1981; Gecas 1982; Gecas \& Schwalbe 1983; Mruk 2006). When people perceive that they are effective and competent, such perceptions are likely to promote self-esteem. When people perceive that they are ineffective and incompetent, such perceptions are likely to be internalized accordingly. Generally speaking, individuals aspire to achieve certain levels of social status and occupational standing. However, because occupations and income levels are achieved statuses, limited success in these areas may be interpreted as a reflection of personal failure. Self-esteem is likely to suffer as a result.

\subsection{The impact of leaving school in an economic downturn}

Workers who leave school in an economic downturn may be directed towards low wage and otherwise less desirable jobs in the short run as there are fewer open jobs and the quality of open jobs declines in economic downturns (Reder 1955; Okun 1973; McLaughlin \& Bils 2001). Labor studies show that labor market frictions limit the ability of workers to shift into better jobs 
as the economy rebounds, leaving workers persistently stuck in low-wage and otherwise less desirable jobs (Oyer 2006, 2008; Genda et al. 2010; Kahn 2010; Kwon et al. 2010; Schoar \& Zuo 2011; Oreopoulos et al. 2012). For example, Kahn (2010) finds that a 1 percentage point increase in the state unemployment rate at school-leaving leads to an annual wage loss of 2.5 to $9 \%$ and is observable 15 years after school-leaving among white male college graduates in the NLSY79 (the data set that we utilize in this study). Moreover, workers who leave school in an economic downturn hold less prestigious jobs and are less likely to be promoted (Kahn 2010; Kwon et al. 2010). Failure to succeed in the labor market may lead to poor self-esteem among individuals who leave school in an economic downturn. Regardless of the effort school-leavers apply to their career, frictions in the labor market prevent them from achieving the success experienced by their more fortunate counterparts who left school in a stronger economy.

The career effects attributable to leaving school in an economic downturn are not uniform across workers, however. Kondo (2007) shows that African American men face higher initial wage penalties but these penalties are more persistent for white men, while Genda et al. (2010) find more persistent wage penalties for high skill (as defined by a college degree) than low skill (as defined by a high school degree) American men. ${ }^{1}$ Women's labor market outcomes may be insulated from economic conditions at school-leaving perhaps because they can more easily substitute into household production when faced with weak opportunities in the labor market (Kondo 2007; Hershbein 2012). Thus, if failure to succeed in the labor market is an important mechanism for self-esteem development we will observe the strongest self-esteem effects for men, and in particular white and higher skill men.

In addition to the above mentioned employment based-channels, leaving school in an economic downturn may affect self-esteem through marriage and human capital accumulation.

\footnotetext{
${ }^{1}$ Genda et al (2010) demonstrate a different pattern of results among Japanese men: high school graduates who leave school in an economic downturn experience larger career penalties than college graduates. These findings are attributed to the structure of the Japanese labor market.
} 
A man who leaves school in an economic downturn and obtains a low paying job may have poor marriage market opportunities, and he may decide to forego marriage. Maclean et al. (2013) examine the impact of leaving school in an economic downturn on marriage and fertility outcomes. Although all men who leave school in an economic downturn are less likely to be married and have children, the effects are strongest for minorities and mid-skill men. ${ }^{2}$ This mechanism may be less pertinent for women based on standard economic models of specialization within the family (Becker 1973; Becker 1981).

Workers, particularly men, who leave school in an economic downturn may seek out education as lower wages reduce the opportunity cost of education (Kahn 2010; Hershbein 2012). If self-esteem is bolstered through human capital accumulation, then perhaps leaving school in an economic downturn may actually lead to improvements in self-esteem. Because the empirical evidence suggests that both high and low skill men return to school when faced with an economic downturn at school-leaving, if education is an important mechanism we will observe effects for men of all skill levels. To the best of our knowledge there is no evidence on heterogeneity by race or ethnicity in this relationship.

Reduced labor market success may allow workers to better balance work and family responsibilities. If investing in non-market activities (e.g., spending time with children, producing meals) improves self-esteem through improved relationship quality or some other means, then leaving school in an economic downturn will increase self-esteem. Because women are more likely to report work-family conflict than men (MacDonald et al. 2005; Uriarte-Landa \& Hebert 2009), we might expect this channel to be stronger for women than for men.

An emerging economic literature documents the importance of non-cognitive traits, ${ }^{3}$

\footnotetext{
${ }^{2}$ Maclean et al (2013) define skill based on the age-adjusted Armed Forces Qualifying Exam (AFQT), a well utilized measure of ability in the economics literature. The authors stratify the sample into terciles of the ageadjusted AFQT score and identify the strongest marriage effects among the second tercile of the AFQT score.

${ }^{3}$ This literature has focused on personality traits (e.g., the Big Five taxonomy), risk aversion or time preference,
} 
which encompass self-esteem, for a wide range of labor market, marriage, health, and education outcomes (Heckman \& Rubinstein 2001; Semeijn et al. 2005; Heckman et al. 2006; Mueller \& Plug 2006; Chiteji 2010; Almlund et al. 2011; Heineck 2011; Heckman \& Kautz 2012; Fletcher 2013). Thus, it may be that leaving school in an economic downturn lowers self-esteem, which in turns influences these other important outcomes. Whether self-esteem is a mechanism through which leaving school in an economic downturn impedes social outcomes or if the reverse relationship is true is ex ante ambiguous.

Although the separate strands of related literature do not provide an entirely clear prediction on whether leaving school in an economic downturn will help or hinder self-esteem, they do suggest that such a relationship exists. We take this question to the data.

\section{Data, variables, and methods}

\subsection{Data}

We draw data from the restricted use National Longitudinal Survey of Youth 1979 Cohort (NLSY79). The original sample consists of 12,686 youth 14 to 22 in 1979 . The survey was administered annually by the Bureau of Labor Statistics (BLS) between 1979 and 1993, and bi-annually from 1994 to 2010 . We exclude subsamples dropped by the NLSY79 for financial reasons (military sample in 1984 and the low income white sample in 1992). We delete respondents who left school before 1976 as state-level unemployment rates from the Bureau of Labor Statistics Local Area Statistics (detailed later) are available from 1976 onwards and we exclude those who report no completed education. We retain observations from NLSY79 rounds in which self-esteem information was collected, leaving an analysis sample of 2,817 men and 3,090 women. Thus, our sample size is in line with other studies that utilize the NLSY79 to examine the persistent effects of leaving school in an economic downturn (Kondo 2007; Kahn 
2010; Hershbein 2012; Maclean 2013; Maclean 2014).

\subsection{Self-esteem measures}

We measure self-esteem with the Rosenberg self-esteem scale (Rosenberg 1965). This scale is commonly utilized within the economic literature to measure self-esteem (Heckman et al. 2006), and is considered a reliable and valid quantitative tool for self-esteem assessment (Blascovich \& Tomaka 1991; Mruk 2006). The scale is collected three times in the NLSY79: 1980 (when cohort members are 15 to 23 years old), 1987 (when cohort members are 27 to 35 years old), and 2006 (when cohort members are 41 to 49 years old). We utilize only the 1987 and 2006 scores as a large proportion of our sample (57\%) had not left school by 1980 . Thus, we observe self-esteem for school-leavers in the early stages of their career and in mid-career. We chose not to include the 1980 score as a control variable in our regression models as this sore may be influenced by our primary regressor of interest -- economic conditions at schoolleaving -- for pre-1980 school-leavers and not for post-1980 school-leavers.

The Rosenberg scale, measured with a ten-item Likert format (four possible responses ranging from strongly agree to strongly disagree) asks respondents to describe their perceptions of their own worthiness and competence. See Table 1 for the full listing of the questions. For ease of interpretation, we utilize the percentile z-score developed by NLSY79 administrators, thus the score ranges from 0 to $100 .^{4}$ A respondent who with a self-esteem score of 75 has higher self-esteem (at least as measured by the Rosenberg scale) than 75 percent of the NLSY79 sample that completed the test. We exclude respondents who do not provide valid scores in 1987 and 2006, and therefore observe each respondent twice. Examining the balanced panel allows us to circumvent compositional effects but does require that we focus on a selected sample. As we detail in a later section results are robust to relaxing this restriction, however.

\footnotetext{
${ }^{4}$ Results are robust if we apply a logit transformation to address the bounded nature of the scale.
} 


\subsection{School-leaving}

The key explanatory variable in this study is the economic conditions at school-leaving. We focus on the first period of school-leaving which occurs once for each respondent. The leaving school definition includes both students who graduated with a degree and who dropped out prior to degree completion. Put differently, both completers and drop-outs are included in our analysis sample. We utilize responses to education history questions fielded between 1979 and 1998 to identify the year the respondent left school for the first time. Because we examine the 1987 variable, we exclude those who left school after 1987 . We require that respondents report being out of school for a period of two years after school-leaving to avoid incorrectly classifying short departures (e.g., travelling abroad for a year) as true school-leaving.

We utilize NSY79 provided geocodes to determine the state of residence at schoolleaving. Respondents who left school between 1976 and 1978 are assigned the 1979 interview state. This imputation assumes that individuals do not move across state lines between schoolleaving and the 1979 interview. We suspect that this assumption does not substantially impact our findings as only $3 \%$ of the U.S. population migrates across state lines annually and this rate has been fairly constant over time (U.S. Census Bureau 2012). The interview state is assigned to respondents who left school between 1979 and 1987. The annual school-leaving cohort sizes are: 371 (1976); 531 (1977); 768 (1978); 881 (1979); 701 (1980); 749 (1981); 695 (1982); 459 (1983); 303 (1984); 205 (1985); 152 (1986); and 92 (1987).

Consistent with the previous literature on the career, marriage, education, and health effects of leaving school in an economic downturn (Kahn 2010; Hershbein 2012; Oreopoulos et al. 2012; Maclean 2013), we proxy economic conditions with the seasonally adjusted annual state unemployment rate. Although no single variable can fully characterize economic activity in an economy, the unemployment rate is one of the indicators utilized by the National Bureau 
of Economic Research (2010) to date business cycles and the Federal Reserve System to track economic trends. Moreover, as we document in a later section of this manuscript, our findings are robust to utilizing alternative measures of economic activity.

Figure 1 reports the quasi-experiment we exploit: the average annual state unemployment rate is plotted between 1976 and 1987. These data are drawn from the BLS Local Area Unemployment Statistics. During this period the U.S. experienced two recessions (January 1980 to July 1980 and July 1981 to November 1982), a period of high inflation in the late-1970s, and a period of economic growth in the mid-1980s. Thus the 1976 to 1987 period arguably provides sufficient variation in economic activity to identify the self-esteem effects.

\subsection{Control variables}

In all regressions we include a set of pre-determined variables that are expected to predict self-esteem: race/ethnicity (African American and Hispanic, with White as the omitted group) (Twenge \& Crocker 2002), foreign birth (Porter \& Washington 1993), a proxy for ability (age-standardized Armed Forces Qualification Test [AFQT]) (Brack et al. 1988), and parental education (mother's and father's years of education (Rosenberg \& Pearlin 1978; Twenge \& Campbell 2002). We do not include variables that are potentially influenced by leaving school in an economic downturn (e.g., age or education at school-leaving, wages or marital status measured in 1987 or 2006) to avoid bias from over-controlling (Angrist \& Pischke 2009). We also include indicators for missing covariates and assign missing observations the sample mean (continuous variable) or mode (binary variable) in our regression models. Lastly we include the number of years (entered linearly) between the school-leaving period and the periods in which the Rosenberg scales are measured (1987 and 2006).

The AFQT, our proxy for ability, is a multiple choice test that it utilized by the U.S. Military to determine qualification for enlistment in the U.S. Armed Forces. It is commonly 
utilized within the economics literature to proxy ability (Heckman et al. 2006). The test measures knowledge and skill in 10 areas: general science, arithmetic reasoning, word knowledge, paragraph comprehension, numerical operations, coding speed, auto and shop information, mathematics knowledge, mechanical comprehension, and electronics information. The score is converted into a percentile by NLSY79 administrators, thus a score of 99 implies that the test-taker out-performed $99 \%$ of the sample. More information on this score is available through the NLSY79 website (https://www.nlsinfo.org/content/cohorts/nlsy79/topicalguide/education/aptitude-achievement-intelligence-scores; accessed 10/3/2013). NLSY79 respondents were administered the AFQT in 1981 at 16 to 24 years. To account for differences in maturing and schooling that vary with age, we follow Kahn (2010) and age-standardize the score by subtracting by the age group mean and dividing by the age group standard deviation.

\subsection{Empirical model}

Equation (1) presents the regression model we utilize the estimate the persistent effects of leaving school in an economic downturn on self-esteem:

$$
E_{i s t}=\alpha_{0}+\alpha_{1} U_{s t}+\alpha_{2}^{\prime} X_{i s t}+\alpha_{3}^{\prime} S_{s}+\alpha_{4}^{\prime} D_{t}+\varepsilon_{i s t}
$$

$E_{i s t}$ is the self-esteem scale measured for individual $i$ in school-leaving state $s$ and school-leaving year $t$ (where $t$ is either 1987 or 2006). $U_{s t}$ is the state unemployment rate in school-leaving state $s$ and school-leaving year $t, X_{i s t}$ is a vector of personal characteristics and years since school-leaving described earlier. $S_{s}$ and $D_{t}$ are vectors of school-leaving state and year fixed effects. Inclusion of the school-leaving state fixed effects implies that we use within school-leaving state variation in unemployment rates to identify self-esteem effects. These fixed effects control for time invariant and difficult-to-observe between school-leaving state differences that may be correlated with both the school-leaving state unemployment rate and 
self-esteem. Lastly, $\varepsilon_{\text {ist }}$ is the error term. ${ }^{5}$

We utilize ordinary least squares (OLS) and estimate equations separately by sex given different labor market participation patterns between men and women (Blau \& Kahn 2007). We apply NLSY79 sample weights for the sample that participated in the 1987 and 2006 surveys, and cluster standard errors around the school-leaving state to account for correlated errors.

Identification of Equation (1) hinges on the assumption that the state unemployment rate at school-leaving is uncorrelated with the error term in the self-esteem equations after we condition on personal characteristics and the various fixed effects detailed earlier. An obvious concern is that the time or location of school-leaving is endogenous to the unemployment rate (Oyer 2006; Kondo 2007; Oyer 2008; Kahn 2010; Oreopoulos et al. 2012; Maclean 2013). School-leavers may engage in endogenous sorting to avoid leaving school in an economic downturn. Endogenous sorting may entail altering the time (e.g., enrolling in additional schooling, dropping out) or location (e.g., moving to a stronger labor market) of school-leaving.

Signing the bias attributable to endogenous sorting is difficult ex ante. School-leavers who avoid economic downturns may have unobservable characteristics (e.g., forethought, understanding of business cycles, financial resources) that permit avoidance behavior. Alternatively, only the most capable and hard-working individuals may be willing to leave school in an economic downturn, as they know that their abilities will allow them to secure desirable jobs regardless of the economic conditions they face. Lastly, myopic individuals, or those who display hyperbolic discounting, may be willing to drop out of school before their education is complete to take advantage of an economic upturn. There is little empirical evidence available on these behaviors, although Wozniak (2010) shows that college graduates are more likely to move to stronger labor markets than high school graduates, suggesting that

\footnotetext{
${ }^{5}$ Results are consistent, although parameters are less precisely estimated, to the inclusion of school-leaving statespecific linear time trends.
} 
those who engage in endogenous sorting may be more advantaged.

An additional concern is measurement error in the school-leaving variables. Recall that we rely on self-reported year of school-leaving; which may be reported with error particularly for those who left school before the survey began (for example, there are three years between the first year of the NLSY79 survey and 1976, the first year members of our analysis sample reported leaving school). Classical measurement error will attenuate OLS estimates, while the direction of systematic measurement error is ambiguous (Bound et al. 2001).

We rely on instrumental variables to address these sources of bias. Following the literature on the career effects of leaving school in an economic downturn we select instruments that have been utilized successfully in previous studies (Oyer 2006; Kondo 2007; Kahn 2010; Oreopoulos et al. 2012; Maclean 2013) and are based on birth year, state of residence at age 14, and early educational expectations. The compliers to these IVs are respondents who do not deviate from their educational plans in response to economic conditions. Both instruments assume respondents adhere to normal school-starting ages and progression through school.

The first instrument, the "on time" state unemployment rate, utilizes state unemployment rate variation that is generated exogenously by birth year and early life residential decisions (these decisions are likely made by parents not school-leavers). For example, we assign a college graduate the annual state unemployment rate in the year she turned 22 (modal schoolleaving age for college graduates in our sample) in the state of residence at age 14 . We make comparable assignments for all educational levels. We delete respondents who did not reside in the U.S. at age 14 as we cannot match them to an age 14 state of residence, and use historical compulsory schooling laws to calculate school start dates (Acemoglu et al. 2001).

We use a second IV (Maclean 2013; Maclean 2014) ${ }^{6}$ : the "respondent expected" school-

\footnotetext{
${ }^{6}$ The authors thank David Card for suggesting this instrument.
} 
leaving state unemployment rate. We construct respondent expected state unemployment rates using birth date and 1965 school start dates, reported educational expectations in 1979, and state of residence at age 14. In 1979 respondents were asked "What level of education do you expect to attain?" If a respondent did not supply valid information in 1979, we use information first from the 1981 round and second from the 1982 (this question was not administered in later rounds). Respondents who do not provide a valid response are coded as missing. For example, we assign a respondent who reported that he expected to complete high school the June unemployment rate in the year he turns 18 in state of residence at age 14 . We make similar assignments for all levels of expected education. Thus, with this instrument we predict the actual school-leaving state unemployment rate using the state unemployment rate the respondent would have faced if he left school at his expected time (as indicated in 1979).

Because the period of school-leaving is potentially endogenous, so is the time since school-leaving. Thus, we instrument the time since school-leaving with the time since schoolleaving implied by the 1) on time instrument and 2) the respondent-expected instrument. For example, if a respondent is 41 in 2006 and left school with a college degree the time since school-leaving implied by the on time instrument is 19 years. $^{7}$

\section{Results}

\subsection{Sample characteristics}

Summary statistics are reported in Tables 2A (men) and 2B (women). We report summary statistics for the full sample, and for individuals who left school when the state unemployment rate was less than and greater than (or equal to) the sample mean school-leaving unemployment rate. Put differently, the former groups of school-leavers left school under better economic conditions than the latter groups. Stratifying the sample in this manner allows us to

\footnotetext{
${ }^{7}$ A respondent who is 41 in 2006 was born in 1964, and would have completed a college degree in 1987 if he followed normal school entry ages and progression, and did not engage in endogenous sorting. Thus, in 200619 years will have passed since he left school "on time".
} 
provide an unadjusted analysis of the effect of leaving school in an economic downturn on selfesteem across the life course.

The mean Rosenberg score in 1987 and 2006 among men is 55.3 and 52.9, and among women the scores are 50.8 and 49.4 respectively. Thus, consistent with previous work men, on average, have higher self-esteem than women (Rosenberg 1965; Kling et al. 1999; Mruk 2006). Interestingly, in 1987 both men and women who left school in relatively under relative poor economic conditions have higher self-esteem and these differences are statistically significant $(p$ $<0.01)$. By 2006, the direction of the difference remains but the gap is smaller and less precise (indeed, the gap is statistically indistinguishable from zero among men).

The average state unemployment rate at school-leaving is 7.57 among men and 7.56 among women. The mean school-leaving year for both men and women is 1980 (thus just ahead of the severe 1981 to 1982 recession), and in the average number of years since school-leaving is 17. The demographics of the NLSY79 sample are comparable to members of this age cohort.

We next divide the sample into two groups: respondents who left school when the state unemployment rate was 1) less than the sample mean rate and 2) greater than/equal to the sample mean rate. Although some of the differences between the groups are statistically different from zero, these two groups look fairly similar in terms of the characteristics we consider here. An obvious exception is the school-leaving state unemployment rate, which is substantially higher among the latter group of school-leavers.

\subsection{Regression results}

Table 3 reports selected OLS estimates of the effect of leaving school in an economic downturn on self-esteem. We present separate models for self-esteem measured in 1987 and 2006 to document the evolution of the relationship across the life course. The top panel reports results for men and the bottom panel pertains to women. 
Our findings suggest that leaving school in an economic downturn reduces self-esteem, but the effect does not emerge immediately. Moreover, the effect is stronger among men than women. For example, among men a 1 percentage point increase in the school-leaving state unemployment rate leads to 0.91 unit (1.65\%) increase in the 1987 score and a 1.80 unit (3.39\%) decrease in the 2006 score. The coefficient in the 1987 regression is imprecisely estimated while the coefficient in the 2006 regression is statistically significant $(p<0.05)$. We observe a similar pattern of results among women, although the coefficients are smaller and imprecisely estimated in both 1987 and 2006.

\subsection{Instrumental variables}

The key empirical challenge in this study is bias from endogenous sorting and measurement error in the school-leaving variables. To address these potential sources of bias, we estimate two-stage least squares utilizing the instruments detailed earlier in the manuscript.

Before reporting results from the IV models, we first provide some evidence on the validity of our selected instruments. IVs must predict the endogenous regressor to consistently estimate a local average treatment effect for the compliers. Table 4 presents selected results from first stage regressions: the school-leaving state unemployment rate is regressed on the IVs and other covariates included in Equation (1) using OLS. The IVs are strong predictors of the school-leaving state unemployment rate: the $F$-statistic is roughly 29 in both the male and female samples and well above the minimum standard of 10 (Stock et al. 2002). A 1 percentage point increase in the on time (respondent expected) state unemployment rate is associated with a $0.28(0.06)$ percentage point increase in the school-leaving state unemployment rate among men $(p<0.01)$. The results are similar in size among women, although the coefficient on the respondent-expected state unemployment rate is less precisely estimated $(p<0.05)$.

Valid IVs must also be excludable from Equation (1). This assumption is difficult to test 
statistically, however. To provide some suggestive evidence we regress each IV on the personal characteristics included in Equations (1) using OLS. Selected results are presented in Table 5. The personal characteristics are generally not strong predictors of the IVs suggesting that the instruments are excludable. The $F$-statistics from the test of joint personal characteristics in all regressions range from 0.69 to 3.55 . However, the $F$-statistics are in some cases statistically different from zero. Taken together, we argue that this evidence suggests that our selected variables are suitable instruments for the school-leaving state unemployment rate.

Table 6 reports selected results from the instrumental variables models. OLS results are replicated for comparison. The relationships identified in our OLS regressions remain after instrumenting, but coefficients are somewhat larger. Among men a 1 percentage point increase in the school-leaving state unemployment rate increases the self-esteem score by 1.16 units $(2.1 \%)$ in 1987 and reduces the self-esteem score by 2.13 units $(4.03 \%)$ in 2006 . The coefficient in the 1987 regression is statistically indistinguishable from zero, however. Effects are again consistent among women, but the estimated coefficients are never statistically significant.

Appendix Table A reports results generated in just-identified models (i.e., instrumenting with either the on time or respondent expected instrument). The coefficients are highly consistent across the different specifications. For example, the coefficient for the school-leaving state unemployment rate in the male 2006 regression ranges from -1.80 to -2.29 . Thus, the results do not suggest that our results are sensitive to the use of one particular IV.

\subsection{Heterogeneity by race/ethnicity and skill level}

Economic research documents differences in the career and marriage penalties attributable to leaving school in an economic downturn by personal characteristics. To explore heterogeneity in the self-esteem effects, we stratify our sample first by race/ethnicity (whites vs. 
non-whites) ${ }^{8}$ and second by skill as defined by the AFQT score. In our analysis by skill level, we divide the sample into three skill terciles based on the age-adjusted AFQT score. Put differently, we use only our analysis sample to define the skill groups. The range of ageadjusted AFQT scores by tercile is: -1.65 to -0.57 in the bottom tercile; -0.56 to 0.45 in the middle tercile; and 0.46 to 2.79 in the top tercile. We choose to stratify the sample using the AFQT score rather than completed education at school-leaving, as the latter measure is more suspect to endogeneity concerns (for example, if individuals engage in endogenous sorting).

Tables 7A and 7B report results by race/ethnicity for men and women respectively. We report results generated in OLS and two-stage least squares regressions. Among men, we find that the relationships observed in the full sample appear to be driven mainly by white men. Among this group of men the coefficient in the 1987 regression is positive (although imprecise) and the coefficient in the 2006 regression is negative. Specifically, in the IV model a 1 percentage point increase in the state unemployment rate at school-leaving leads to a 1.61 unit $(2.86 \%)$ increases in the self-esteem score in 1987 and a 2.58 unit (4.84\%) decrease in this score in 2006 among white men. The pattern of results among non-white men is more mixed; coefficients are never statistically different from zero. Findings for both white and non-white women are consistent with the full sample results: the coefficients on the school-leaving state unemployment rate are positive (negative) in the 1987 (2006) recession, but generally imprecise and small in magnitude.

We next turn to results for specific skill groups. Tables $8 \mathrm{~A}$ and $8 \mathrm{~B}$ report results for men and women respectively. In general, the results are strongest for the high skill group and in particular high skill men (one exception is the middle skill group of men: the coefficient estimated in the 1987 regression is positive and statistically significant in both the OLS and IV

\footnotetext{
${ }^{8}$ We choose not to separate African Americans from Hispanics as the sample sizes become very small. For example, there are less than 500 Hispanic males in our analysis sample.
} 
models). Moreover, among high skill the negative effect of leaving school in an economic downturn is evident in both 1987 and 2006 (although the former relationship is imprecise). In this group a 1 percentage point increase in the school-leaving state unemployment rate leads to a 0.30 to 0.45 unit $(0.47 \%$ to $0.71 \%)$ decrease in self-esteem in 1987 and a 3.98 to 5.79 unit $(6.60 \%$ to $9.60 \%)$ decrease in self-esteem in 2006 .

\section{Robustness Checks}

In this section we assess the robustness of our findings to alternative proxies of economic conditions at school-leaving and model specifications.

As discussed in an earlier section of this manuscript, the state unemployment rate is but one proxy for economic conditions. Moreover, it is potentially endogenous to the true economic conditions, as discouraged workers may exit the labor market in downturns and return when conditions improve. In Appendix Table B, we report estimates generated in models that proxy economic conditions with 1) the annual state employment-to-population ratio from the BLS and 2) annual state per capita income (1,000s) from the University of Kentucky Center for Poverty Research (inflated to 2010 dollars using the Consumer Price Index). The results are consistent with results generated in our core model, although the signs on the coefficient estimates are reversed (i.e., positive) as increases in both the school-leaving employment-to-population ratio and per capita income represent improvements in economic conditions. This check suggests that our findings are not driven by an endogenous measure of economic activity.

We next estimate what we term "long" versions of Equation (1), and results are reported in Appendix Table C. That is, we include additional background characteristics to the $X_{i s t}$ vector. Including such variables may better control for individual heterogeneity which may be correlated with self-esteem, and leaving school in an economic downturn. Thus, the long version of Equation (1) may better address bias from omitted variables than our core models. 
Specifically, we augment $X_{\text {ist }}$ with an indicator for living in a rural vs. urban area at age 14 , an indicator for speaking a language other than English in the home at age 14, and access to educational materials in the home at age 14 (library cards, magazines, newspapers). ${ }^{9}$ The coefficients are robust across the different covariate sets, lending credence to the argument that our findings represent causal effects rather than simple correlations.

As noted in an earlier section of this manuscript, we choose to focus on the balanced panel of results (that is respondents for whom we observe a valid self-esteem score in both 1987 and 2006). An advantage of examining the balanced panel is that we are able to circumvent compositional effects (put differently because the sample with valid self-esteem scores changes between 1987 and 2006, it is not clear how much of the change in coefficient can be attributed to a different sample). A disadvantage of this focus is that we examine a selected sample. We next report results based on the unbalanced panel, put differently we include any respondent who provided a valid self-esteem score in 1987 or 2006. Results are reported in Appendix Table D. The results are highly consistent with those generated in the balanced sample and suggest that that focusing on the balanced panel does not induce substantial bias into our estimates. ${ }^{10}$

\section{Discussion}

In this study, we expand the literature on the life course effects of leaving school in an economic downturn. Previous studies have focused on outcomes related to careers, marriages, academics, and health. We extend this body of work by focusing on self-esteem. We show that leaving school in an economic downturn leads to lower self-esteem, but the effects do not emerge until middle age. Moreover, findings are stronger from men than women, and in particular non-minority and high skill men. In our preferred specification, a 1 percentage point increase in the school-leaving state unemployment rate leads to a 2.13 unit $(4.03 \%)$ reduction in

\footnotetext{
${ }^{9}$ To preserve sample size we assign observations with missing information the mode and include indicators for missingness in our regression models.

${ }^{10}$ This test does not address bias from those who attrite from the sample, or refuse to complete the Rosenberg test.
} 
the Rosenberg self-esteem score among middle age men.

A growing line of economic research emphasizes the importance of non-cognitive skills - such as personality traits, self-esteem, time preference, and locus of control -- for social outcomes. Thus, it may be that leaving school in an economic downturn leads to lower social outcomes, which in turn erodes self-esteem. Alternatively leaving school in an economic downturn is detrimental to school-leaving, leading to worse performance in the labor and marriage markets, and worse health. However, the timing of our findings, taken together with other findings in the related literature, suggests that the former temporal ordering is more likely. To see this, recall that the career and marriage effects emerge soon after school-leaving for most demographic groups while we do not observe deterioration in self-esteem until middle age. Instead, we find some (albeit weak) evidence that leaving school in an economic downturn may increase self-esteem in the short-run. The direction of the self-esteem-career/marriage/health relationships need not be entirely one-directional, however. For example, once self-esteem begins to decline it may exacerbate already poor labor and marriage market outcomes (e.g., an employee with low self-esteem is less likely to be selected for promotion or receive a raise; a partner with low self-esteem may create problems in an already unstable marriage). Future research could more rigorously examine these pathways, as our data will not permit us to conduct a more formal analysis of mechanisms.

Our analysis of heterogeneous effects by race/ethnicity and skill level suggests that it is typically more advantaged groups who are most vulnerable to leaving school in an economic downturn in terms of self-esteem: white and high skill men. Although this finding is perhaps counter-intuitive as these more advantaged groups are often believed to be more resilient than less advantaged groups, it is consistent with previous work on the career effects of leaving school in an economic downturn. For example, white, high skill, and white collar workers 
(particularly men) receive the most persistent wage penalties attributable to leaving school in an economic downturn. Perhaps, because these groups are advantaged, they have more to lose in terms of labor market success (e.g., their skills will yield high wages ceteris paribus). Moreover, they may have had higher expectations for themselves in terms of their career and may compare themselves with a more successful peer group than less advantaged groups.

Although there is sparse evidence on the persistent marriage effects of leaving school in an economic downturn, some research suggests that the marriage penalties are strongest for middle skill and minority men (Maclean et al. 2013). Because we find the largest self-esteem effects among white and high skill men, marriage may not be the dominant mechanism here. Instead poor labor market performance may be particularly important for self-esteem. Relatedly, education and work-family balance may not be the most relevant mechanisms for self-esteem development across the adult life course.

That we find positive, although generally imprecise, self-esteem effects in 1987 and negative self-esteem effects in 2006 is worthy of some discussion (an exception are high skill men for whom we observe negative self-esteem effects in both the 1987 and 2006 surveys, although the former is imprecise). This pattern of results is not fully consistent with the hypothesis that leaving school in an economic downturn monotonically erodes self-esteem through exposure to poor labor market, marriage, and health experiences. In 1987 members of the NLSY79 cohort are 22 to 30 years of age, while in 2006 they are 41 to 49 years. Perhaps in 1987 less demanding careers and remaining single allows individuals to take advantage of leisure time activities and return to school, and minimizes stress from work and family responsibilities. At the same time, these individuals may hope that they will "catch-up" to their peers in terms of career and marriage. Moreover, they may not be fully aware of the gap between their outcomes and that of their peers, as previous work shows that the early career is 
characterized by job-churning and "shopping around," which may mask true career trajectories (Neumark 2002). However, as time passes, individuals who left school in an economic downturn realize that they will not catch-up, and the utility they derive from socializing and continuing education wanes. At this point the reality of their poor career and marriage trajectories becomes evident and their self-esteem begins to decline. Unfortunately, these mechanisms are speculative and our data do not allow us to explore them.

This work builds on recent work by Maclean (2014) that examines the persistent effect of leaving school in an economic downturn on alcohol use and misuse. In an extension to the main analysis, the author documents that self-esteem is influenced by leaving school in an economic downturn. We make important contributions to this work, however. First, we study dynamics and are thus able to capture important aspects of the relationship that are missed by Maclean (2014). Second, we are able to study heterogeneity (e.g., skill and race/ethnicity) across worker type. For example, we find that high skill and white men experience the largest reductions in self-esteem and this information is not available in Maclean's study. Third, we show that this finding is highly robust to multiple sensitivity tests, and thus are able to document the association is perhaps better interpreted as a causal effect rather than a correlation.

Like much empirical work, this study has several limitations. The NLSY79 administered the Rosenberg self-esteem scale three times, and we utilize only two of these rounds, thus we are unable to explore the full life course evolution of this relationship. Although the Rosenberg scale is commonly utilized to measure self-esteem and has been validated in many settings, it is but one proxy for self-esteem. Lastly, because the NLSY79 contains only one cohort, it is unclear how well findings generalize to the broader population. Work by Altonji et al. (2012) comparing the NLSY79 and the National Survey of Youth 1997 Cohort (NLSY97), the latter a comparable survey designed to track labor market and other social outcomes across the life 
course in a nationally representative sample of American youth ages 12 to 16 in 1997, suggests that there have been only modest changes in the characteristics of youth between these surveys. Taken in this light, our findings may indeed be informative for more recent cohorts.

One important exception is women. Female labor force participation rates have increased substantially since the NLSY79 sample left school: in 1976 (the first year members of our sample left school) the adult female labor market participation was $42.9 \%$ (Bureau of the Census 1976) and by 2013 adult women's participation rate was 58.7\% (Bureau of Labor Statistics 2013). Because today's women may "look" more like NLSY79 men than NLSY79 women, we might expect that they will experience similar self-esteem effects as NLSY79 men. Further work could explore this question in younger cohorts, such as the NLSY97, when women's labor market attachment is higher.

Our findings suggest that the full effects of leaving school in an economic downturn will extend a broader set of outcomes, and perhaps a larger group of individuals, that previously considered. Because self-esteem is linked with civic engagement and deviant behavior, and these behaviors have implications for social welfare, understanding how these outcomes are influenced by economic conditions faced at school-leaving may be worthwhile. In addition, future work could consider whether other non-cognitive traits that are linked with social outcomes, such as mastery, are also influenced by economic conditions at school-leaving and how the self-esteem effects evolve as individuals enter older ages. 
Table 1. Rosenberg Self-Esteem Scale: 1987 and 2006

\begin{tabular}{ll}
\hline \hline Question number & Question Wording \\
\hline 1 & I am a person of worth. \\
\hline 2 & I have a number of good qualities. \\
\hline 3 & I am inclined to feel that I am a failure. \\
\hline 5 & I am able to do things as well as most other people. \\
\hline 6 & I felt I do not have much to be proud of. \\
\hline 7 & I take a positive attitude toward myself. \\
\hline 9 & I am satisfied with myself. \\
\hline 10 & I wish I could have more respect for myself. \\
\hline
\end{tabular}

Notes: Scoring for items 1, 2, 4, 6, and 7: strongly agree=3; agree=2; disagree $=1$; and strongly disagree $=0$. $\mathrm{Scoring}$ for items 3, 5, 8, and 10: strongly agree $=0$; agree=1; disagree=2; and strongly disagree $=3$. 
Table 2A. Summary statistics: NLSY79 men

\begin{tabular}{|c|c|c|c|c|}
\hline & \multicolumn{4}{|c|}{$\begin{array}{l}\text { School-leaving state } \\
\text { unemployment rate }\end{array}$} \\
\hline & Full sample & $<$ mean & $\geq$ mean & $\begin{array}{c}\text { Difference } \\
(p \text {-value })\end{array}$ \\
\hline \multicolumn{5}{|l|}{ Self-esteem measures } \\
\hline 1987 score & 55.3 & 53.4 & 57.9 & 0.0001 \\
\hline 2006 score & 52.9 & 52.8 & 52.9 & 0.5894 \\
\hline \multicolumn{5}{|l|}{ School-leaving variables } \\
\hline School-leaving state unemployment rate & 7.57 & 6.05 & 9.67 & 0.0000 \\
\hline School-leaving year & 1980.4 & 1979.9 & 1981.2 & 0.0000 \\
\hline Years since school-leaving & 17.1 & 17.6 & 16.3 & 0.0000 \\
\hline \multicolumn{5}{|l|}{ Personal characteristics } \\
\hline White & 0.80 & 0.79 & 0.80 & 0.0021 \\
\hline African American & 0.14 & 0.14 & 0.14 & 0.6673 \\
\hline Hispanic & 0.061 & 0.068 & 0.053 & 0.0000 \\
\hline Born outside U.S. & 0.030 & 0.035 & 0.023 & 0.0124 \\
\hline AFQT score & 50.5 & 50.4 & 50.6 & 0.4547 \\
\hline AFQT score missing & 0.051 & 0.058 & 0.042 & 0.0010 \\
\hline Mother's years of education & 11.8 & 11.7 & 11.9 & 0.0007 \\
\hline Mother's years of education missing & 0.050 & 0.046 & 0.055 & 0.7246 \\
\hline Father's years of education & 12.1 & 12.0 & 12.2 & 0.0028 \\
\hline Father's years of education missing & 0.093 & 0.10 & 0.082 & 0.0086 \\
\hline $\mathrm{N}$ & 5,634 & 3,340 & 2,294 & \\
\hline
\end{tabular}


Table 2B. Summary statistics: NLSY79 women

\begin{tabular}{|c|c|c|c|c|}
\hline & \multicolumn{4}{|c|}{$\begin{array}{l}\text { School-leaving state } \\
\text { unemployment rate }\end{array}$} \\
\hline & Full sample & $<$ mean & $\geq$ mean & $\begin{array}{c}\text { Difference } \\
(p \text {-value })\end{array}$ \\
\hline \multicolumn{5}{|l|}{ Self-esteem measures } \\
\hline 1987 score & 50.8 & 49.1 & 53.0 & 0.0000 \\
\hline 2006 score & 49.4 & 50.1 & 48.5 & 0.0759 \\
\hline \multicolumn{5}{|l|}{ School-leaving variables } \\
\hline School-leaving state unemployment rate & 7.56 & 6.02 & 9.57 & 0.0000 \\
\hline School-leaving year & 1980.2 & 1979.6 & 1981.0 & 0.0000 \\
\hline Years since school-leaving & 17.3 & 17.9 & 16.5 & 0.0000 \\
\hline \multicolumn{5}{|l|}{ Personal characteristics } \\
\hline White & 0.81 & 0.79 & 0.83 & 0.0000 \\
\hline African American & 0.14 & 0.15 & 0.13 & 0.0016 \\
\hline Hispanic & 0.052 & 0.059 & 0.043 & 0.0000 \\
\hline Born outside U.S. & 0.033 & 0.031 & 0.035 & 0.8200 \\
\hline AFQT score & 49.2 & 48.8 & 49.8 & 0.0001 \\
\hline AFQT score missing & 0.032 & 0.031 & 0.034 & 0.5763 \\
\hline Mother's years of education & 11.7 & 11.6 & 11.9 & 0.0000 \\
\hline Mother's years of education missing & 0.036 & 0.038 & 0.034 & 0.4512 \\
\hline Father's years of education & 11.9 & 11.8 & 11.9 & 0.0000 \\
\hline Father's years of education missing & 0.092 & 0.10 & 0.076 & 0.0000 \\
\hline $\mathrm{N}$ & 6,180 & 3,672 & 2,508 & \\
\hline
\end{tabular}

Notes: NLSY79 sample weights applied. Differences estimated with $t$-tests when the outcome is continuous and $\chi^{2}$ tests when the outcome is binary. 
Table 3. Effect of leaving school in an economic downturn on self-esteem: OLS model

\begin{tabular}{lcc}
\hline \hline Year in which self-esteem is measured & $\mathbf{1 9 8 7}$ & $\mathbf{2 0 0 6}$ \\
\hline Men & & 52.87 \\
\hline Sample mean & 55.29 & $-1.7924^{* *}$ \\
\hline School-leaving state unemployment rate & 0.9111 & $(0.6920)$ \\
& $(0.6921)$ & 2,817 \\
\hline W & 2,817 & 49.42 \\
\hline Sample mean & 50.82 & -0.7938 \\
\hline School-leaving state unemployment rate & 0.3632 & $(0.4871)$ \\
\hline $\mathrm{N}$ & $(0.5687)$ & 3,090
\end{tabular}

Notes: NLSY79 sample weights applied. All models adjust for personal characteristics, and school-leaving state and year fixed effects. Standard errors are clustered around the school-leaving state and are reported in parentheses. $* * * ; * * * *$ statistically significant at the $1 \% ; 5 \% ; 10 \%$ level. 
Table 4. First stage regression results

\begin{tabular}{lcc}
\hline \hline & Men & Women \\
\hline Sample mean & 7.57 & 7.56 \\
\hline On time school-leaving state unemployment rate & $0.2820^{* * *}$ & $0.3176^{* * *}$ \\
& $(0.0399)$ & $(0.0616)$ \\
Respondent-expected school-leaving state unemployment rate & $0.0576^{* * *}$ & $0.0485^{* *}$ \\
& $(0.0159)$ & $(0.0227)$ \\
\hline -statistic of IV joint significance & 28.84 & 29.30 \\
$(p$-value $)$ & $(p<0.0000)$ & $(p<0.0000)$ \\
\hline $\mathrm{N}$ & 5,634 & 6,180 \\
\hline
\end{tabular}

Notes: NLSY79 sample weights applied. All models adjust for personal characteristics, and school-leaving state and year fixed effects. Standard errors are clustered around the school-leaving state and are reported in parentheses. $* * * ; * * ; *=$ statistically significant at the $1 \% ; 5 \% ; 10 \%$ level. 
Table 5. Instrument excludability: Correlates of selected instrumental variables

\begin{tabular}{|c|c|c|c|c|}
\hline & \multicolumn{2}{|c|}{ Men } & \multicolumn{2}{|c|}{ Women } \\
\hline & $\begin{array}{l}\text { On } \\
\text { time }\end{array}$ & $\begin{array}{c}\text { Respondent } \\
\text { expected }\end{array}$ & $\begin{array}{c}\text { On } \\
\text { time }\end{array}$ & $\begin{array}{c}\text { Respondent } \\
\text { expected }\end{array}$ \\
\hline Mean & 7.59 & 7.72 & 7.66 & 7.82 \\
\hline African American & $\begin{array}{c}0.0726 \\
(0.0641)\end{array}$ & $\begin{array}{l}-0.0543 \\
(0.0805)\end{array}$ & $\begin{array}{l}-0.0683 \\
(0.0633)\end{array}$ & $\begin{array}{c}-0.1390 * * \\
(0.0632)\end{array}$ \\
\hline Hispanic & $\begin{array}{c}0.1810 \\
(0.1422)\end{array}$ & $\begin{array}{c}0.0703 \\
(0.0772)\end{array}$ & $\begin{array}{l}-0.0599 \\
(0.0695)\end{array}$ & $\begin{array}{l}-0.0504 \\
(0.0818)\end{array}$ \\
\hline Born outside U.S. & $\begin{array}{l}-0.0781 \\
(0.1894)\end{array}$ & $\begin{array}{l}-0.0689 \\
(0.1522)\end{array}$ & $\begin{array}{c}0.1317 \\
(0.0851)\end{array}$ & $\begin{array}{l}0.1292 * \\
(0.0736)\end{array}$ \\
\hline Age-adjusted AFQT score & $\begin{array}{c}0.0218 \\
(0.0432)\end{array}$ & $\begin{array}{l}-0.0194 \\
(0.0478)\end{array}$ & $\begin{array}{l}-0.0256 \\
(0.0257)\end{array}$ & $\begin{array}{l}-0.0142 \\
(0.0247)\end{array}$ \\
\hline Age-adjusted AFQT score missing & $\begin{array}{c}0.0589 \\
(0.1118)\end{array}$ & $\begin{array}{c}0.1263 \\
(0.1013)\end{array}$ & $\begin{array}{c}0.3932 * * * \\
(0.1248)\end{array}$ & $\begin{array}{c}0.2475 \\
(0.1521)\end{array}$ \\
\hline Mother's years of education & $\begin{array}{c}0.0020 \\
(0.0078)\end{array}$ & $\begin{array}{c}0.0104 \\
(0.0078)\end{array}$ & $\begin{array}{l}-0.0056 \\
(0.0118)\end{array}$ & $\begin{array}{c}0.0090 \\
(0.0100)\end{array}$ \\
\hline Mother's years of education missing & $\begin{array}{c}0.0410 \\
(0.1103)\end{array}$ & $\begin{array}{c}-0.0327 \\
(0.0746)\end{array}$ & $\begin{array}{c}0.2188 \\
(0.1328)\end{array}$ & $\begin{array}{c}0.1475 \\
(0.0946)\end{array}$ \\
\hline Father's years of education & $\begin{array}{l}-0.0091 \\
(0.0066)\end{array}$ & $\begin{array}{c}-0.0193 * * * \\
(0.0059)\end{array}$ & $\begin{array}{l}-0.0120 * \\
(0.0071)\end{array}$ & $\begin{array}{l}-0.0063 \\
(0.0096)\end{array}$ \\
\hline Father's years of education missing & $\begin{array}{l}-0.0093 \\
(0.0676) \\
\end{array}$ & $\begin{array}{l}-0.0042 \\
(0.0925) \\
\end{array}$ & $\begin{array}{c}0.0389 \\
(0.0804) \\
\end{array}$ & $\begin{array}{l}-0.0159 \\
(0.0749) \\
\end{array}$ \\
\hline $\begin{array}{l}F \text {-test of personal characteristics joint significance } \\
(p \text {-value) }\end{array}$ & $\begin{array}{c}0.69 \\
(0.7105) \\
\end{array}$ & $\begin{array}{c}2.50 \\
(0.0201) \\
\end{array}$ & $\begin{array}{c}3.55 \\
(0.0020) \\
\end{array}$ & $\begin{array}{c}1.78 \\
(0.0977) \\
\end{array}$ \\
\hline $\mathrm{N}$ & 5,634 & 5,634 & 6,180 & 6,180 \\
\hline
\end{tabular}

Notes: NLSY79 sample weights applied. All models adjust for school-leaving state and year fixed effects. Standard errors are clustered around the school-leaving and are reported in parentheses.

$* * * ; * ; *=$ statistically significant at the $1 \% ; 5 \% ; 10 \%$ level. 
Table 6. Effect of leaving school in an economic downturn on self-esteem : IV model

\begin{tabular}{lcc}
\hline \hline Year in which self-esteem is measured & $\mathbf{1 9 8 7}$ & $\mathbf{2 0 0 6}$ \\
\hline Men & & 52.87 \\
\hline Sample mean & 55.29 & $-1.7924 * *$ \\
\hline OLS & 0.9111 & $(0.6920)$ \\
& $(0.6921)$ & $-2.1333^{* * *}$ \\
\hline Two-stage least squares & 1.1637 & $(0.7335)$ \\
& $(1.1152)$ & 2,817 \\
\hline $\mathrm{N}$ & 2,817 & 49.42 \\
\hline Women & & -0.7938 \\
\hline Sample mean & 50.82 & $(0.4871)$ \\
\hline OLS & 0.3632 & -0.8836 \\
& $(0.5687)$ & $(1.7617)$ \\
\hline Two-stage least squares & 1.1740 & 3,090 \\
\hline
\end{tabular}

Notes: All models apply NLSY79 sample weights and adjust for personal characteristics. OLS models adults for school-leaving state and year fixed effects. Two-stage least squares models adjust for state of residence at age 14 fixed effects, and on time and respondent on time year fixed effects. Standard errors are clustered by schoolleaving state in OLS and state of residence at age 14 in two-stage least squares. All standard errors are reported in parentheses.

$* * * ; * * *=$ statistically significant at the $1 \% ; 5 \% ; 10 \%$ level. 
Table 7A. Effect school-leaving state unemployment rate on self-esteem: Men by race/ethnicity

\begin{tabular}{lcc}
\hline \hline Year in which self-esteem is measured & $\mathbf{1 9 8 7}$ & $\mathbf{2 0 0 6}$ \\
\hline White men & 56.18 & 53.29 \\
\hline Sample mean & 1.0781 & $-2.3676^{* *}$ \\
\hline OLS & $(0.9591)$ & $(0.9552)$ \\
\hline Two-stage least squares & 1.6067 & $-2.5783 * *$ \\
& $(1.6756)$ & $1.0214)$ \\
\hline Observations & 1468 & 1468 \\
\hline Non-white men & 51.84 & 51.27 \\
\hline Sample mean & 0.7362 & 0.2739 \\
\hline OLS & $(0.9084)$ & $(0.7633)$ \\
\hline Two-stage least squares & -1.3787 & 0.1560 \\
& $(15.0369)$ & $(6.9346)$ \\
\hline Observations & 1349 & 1349 \\
\hline Notes: All models apply NLSY79 sample weights and adjust for personal characteristics. OLS models adults for \\
school-leaving state and year fixed effects. Two-stage least squares models adjust for state of residence at age 14 \\
fixed effects, and on time and respondent on time year fixed effects. Standard errors are clustered by school- \\
leaving state in OLS and state of residence at age 14 in two-stage least squares. All standard errors are reported in \\
parentheses.
\end{tabular}

Table 7B. Effect school-leaving state unemployment rate on self-esteem: Women by race/ethnicity

\begin{tabular}{lcc}
\hline \hline Year in which self-esteem is measured & $\mathbf{1 9 8 7}$ & $\mathbf{2 0 0 6}$ \\
\hline White women & 51.09 & 48.98 \\
\hline Sample mean & 0.2770 & $-0.8627^{*}$ \\
\hline OLS & $(0.7042)$ & $(0.5087)$ \\
& 1.3007 & -2.2448 \\
\hline Two-stage least squares & $(4.2164)$ & $(3.8194)$ \\
\hline Observations & 1648 & 1648 \\
\hline Non-white women & & 51.26 \\
\hline Sample mean & 49.71 & -0.0114 \\
\hline OLS & $1.3329 * *$ & $(0.6381)$ \\
& $(0.6491)$ & -0.8052 \\
\hline Two-stage least squares & 2.0014 & $(1.7944)$ \\
\hline Observations & $(1.4877)$ & 1442 \\
\hline
\end{tabular}

Notes: All models apply NLSY79 sample weights and adjust for personal characteristics. OLS models adults for school-leaving state and year fixed effects. Two-stage least squares models adjust for state of residence at age 14 fixed effects, and on time and respondent on time year fixed effects. Standard errors are clustered by schoolleaving state in OLS and state of residence at age 14 in two-stage least squares. All standard errors are reported in parentheses.

$* * * ; * ; *=$ statistically significant at the $1 \% ; 5 \% ; 10 \%$ level. 
Table 8A. Effect school-leaving state unemployment rate on self-esteem: Men by AFQT score

\begin{tabular}{lcc}
\hline \hline Year in which self-esteem is measured & $\mathbf{1 9 8 7}$ & $\mathbf{2 0 0 6}$ \\
\hline Bottom tercile & & 41.01 \\
\hline Sample mean & 1.1482 & -0.1936 \\
\hline OLS & $(1.2178)$ & $(1.4963)$ \\
\hline Two-stage least squares & -2.0390 & -5.6577 \\
& $(21.5559)$ & $(23.8491)$ \\
\hline Observations & 962 & 962 \\
\hline Middle tercile & & 50.49 \\
\hline Sample mean & 53.03 & -0.2124 \\
\hline OLS & $2.8791 * * *$ & $(1.2570)$ \\
\hline Two-stage least squares & $(1.0347)$ & 1.5859 \\
& $5.3902 *$ & $(2.2650)$ \\
\hline Observations & $(3.0526)$ & 884 \\
\hline Top tercile & 884 & 60.30 \\
\hline Sample mean & & $-3.9759^{* * *}$ \\
\hline OLS & 64.09 & $(1.1695)$ \\
\hline Two-stage least squares & -0.3039 & $-5.7893^{* * *}$ \\
\hline Observations & $(1.3854)$ & $(2.0075)$ \\
\hline Notes: All models apply & -0.4535 & 971 \\
\hline
\end{tabular}

Notes: All models apply NLSY79 sample weights and adjust for personal characteristics. OLS models adults for school-leaving state and year fixed effects. Two-stage least squares models adjust for state of residence at age 14 fixed effects, and on time and respondent on time year fixed effects. Standard errors are clustered by schoolleaving state in OLS and state of residence at age 14 in two-stage least squares. All standard errors are reported in parentheses. The range for the bottom, middle, and top age-adjusted AFQT score tercile is -1.65 to $-0.57 ;-0.56$ to 0.45 ; and 0.46 to 2.79 .

$* * * ; * * ; *=$ statistically significant at the $1 \% ; 5 \% ; 10 \%$ level. 
Table 8B. Effect school-leaving state unemployment rate on self-esteem: Women by AFQT score

\begin{tabular}{lcc}
\hline Year in which self-esteem is measured & $\mathbf{1 9 8 7}$ & $\mathbf{2 0 0 6}$ \\
\hline Bottom tercile & 37.08 & 41.76 \\
\hline Sample mean & 0.2908 & 0.3046 \\
& $(0.9653)$ & $(0.7510)$ \\
\hline Two-stage least squares & 1.7304 & 5.5718 \\
& $(3.2771)$ & $(3.9486)$ \\
\hline Observations & 1,007 & 1,007 \\
\hline Middle tercile & & 49.08 \\
\hline Sample mean & 49.09 & -1.2527 \\
\hline OLS & -0.4107 & $(0.7230)$ \\
\hline Two-stage least squares & $(0.8767)$ & 8.5485 \\
& -5.5000 & $(47.7260)$ \\
\hline Observations & $(23.2202)$ & 1,083 \\
\hline Top tercile & 1,083 & 53.41 \\
\hline Sample mean & & -0.2545 \\
\hline OLS & 58.84 & $(1.3716)$ \\
\hline Two-stage least squares & 0.7739 & -1.7282 \\
& $(0.9010)$ & $(5.7841)$ \\
\hline Observations & -5.4513 & 1,000
\end{tabular}

Notes: All models apply NLSY79 sample weights and adjust for personal characteristics. OLS models adults for school-leaving state and year fixed effects. Two-stage least squares models adjust for state of residence at age 14 fixed effects, and on time and respondent on time year fixed effects. Standard errors are clustered by schoolleaving state in OLS and state of residence at age 14 in two-stage least squares. All standard errors are reported in parentheses. The range for the bottom, middle, and top age-adjusted AFQT score tercile is -1.65 to $-0.57 ;-0.56$ to 0.45 ; and 0.46 to 2.79 .

$* * * ; * ; *=$ statistically significant at the $1 \% ; 5 \% ; 10 \%$ level. 
Figure 1. Average annual state unemployment rates between 1976 and 1987

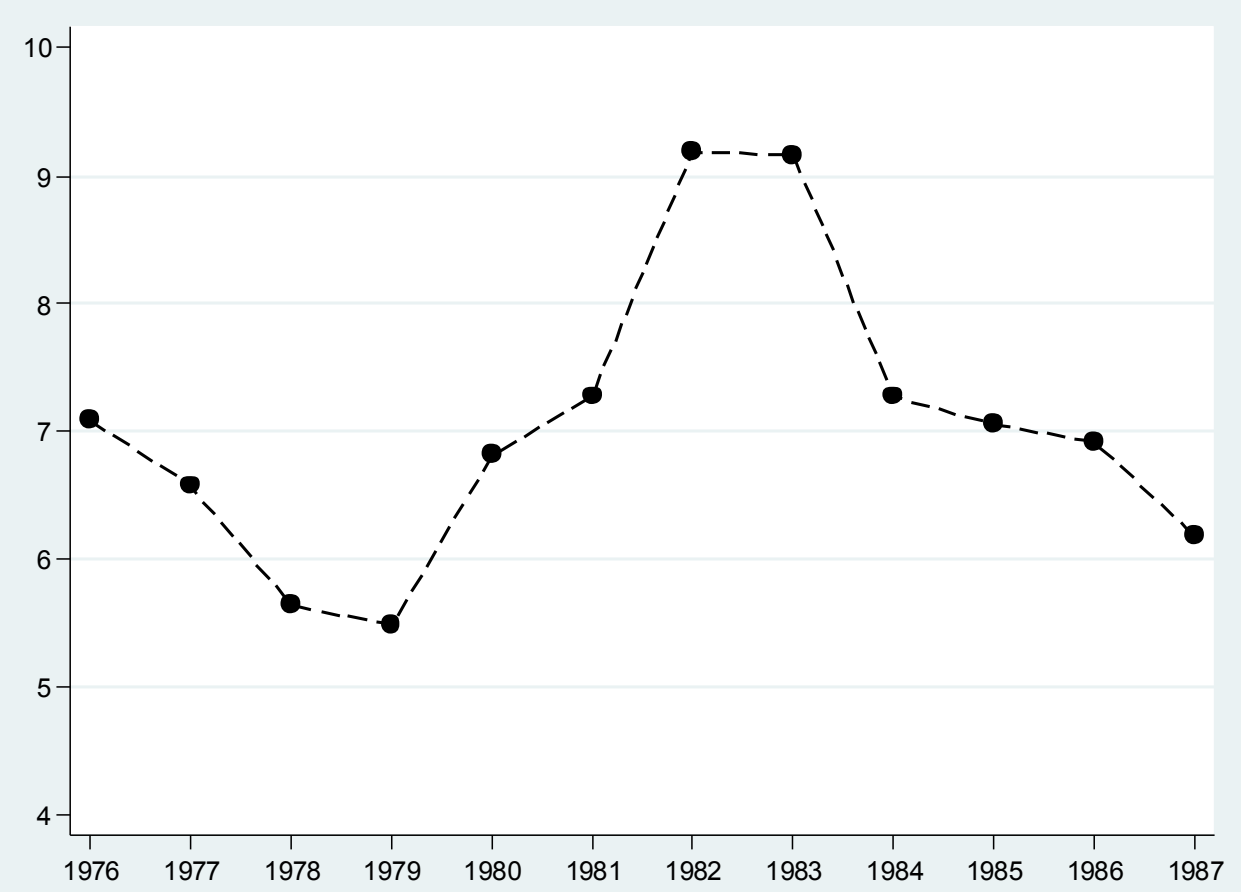

Source: Bureau of Labor Statistics Local Area Unemployment Statistics 
Appendix Table A. Effect of leaving school in an economic downturn on self-esteem: Instrumental variable models with alternative instruments

\begin{tabular}{lcc}
\hline Year in which self-esteem is measured & $\mathbf{1 9 8 7}$ & $\mathbf{2 0 0 6}$ \\
\hline Men & & 52.87 \\
\hline Sample mean & 55.29 & $-2.1333^{* * *}$ \\
\hline Overidentified model & 1.1637 & $(0.7335)$ \\
& $(1.1152)$ & $-1.7964^{* *}$ \\
\hline On time state unemployment rate & 1.1966 & $(0.9119)$ \\
\hline Respondent expected state unemployment rate & $(1.0646)$ & $-2.2938^{* *}$ \\
& 1.3755 & $(0.9067)$ \\
\hline W & $(1.5680)$ & 2,817 \\
\hline Sample mean & 2,817 & 49.42 \\
\hline Overidentified model & 50.82 & -0.8836 \\
& 1.1740 & $(1.7617)$ \\
\hline On time state unemployment rate & $(1.7123)$ & -0.8510 \\
& 0.1022 & $(0.7062)$ \\
\hline Respondent expected state unemployment rate & $(0.7548)$ & -0.8303 \\
\hline
\end{tabular}

Notes: All models apply NLSY79 sample weights and adjust for personal characteristics, state of residence at age 14 fixed effects, and on time and respondent on time year fixed effects. Standard errors are clustered by the state of residence at age 14 and reported in parentheses.

$* * * ; * ; *=$ statistically significant at the $1 \% ; 5 \% ; 10 \%$ level. 
Appendix Table B. Effect of leaving school in an economic downturn on self-esteem: Instrumental variable models with alternative proxies for economic conditions at school-leaving

\begin{tabular}{lcc}
\hline Year in which self-esteem is measured & $\mathbf{1 9 8 7}$ & $\mathbf{2 0 0 6}$ \\
\hline Men & & 52.87 \\
\hline Sample mean & 55.29 & $-2.1333^{* * *}$ \\
\hline School-leaving state unemployment rate & 1.1637 & $(0.7335)$ \\
& $(1.1152)$ & $3.0853^{* *}$ \\
\hline School-leaving employment-to-population ratio & -1.6831 & $(1.3489)$ \\
\hline School-leaving per capita income (1,000s) & $(1.6780)$ & $8.8556^{* * *}$ \\
& -2.7106 & $(3.3397)$ \\
\hline N & $(2.3256)$ & 2,817 \\
\hline Sample mean & 2,817 & 49.42 \\
\hline School-leaving state unemployment rate & & -0.8836 \\
& 50.82 & $(1.7617)$ \\
\hline School-leaving employment-to-population ratio & 1.1740 & 1.4801 \\
& $(1.7123)$ & $(2.9981)$ \\
\hline School-leaving per capita income & -1.9666 & 4.4993 \\
\end{tabular}

Notes: All models apply NLSY79 sample weights and adjust for personal characteristics, state of residence at age 14 fixed effects, and on time and respondent on time year fixed effects. Standard errors are clustered by the state of residence at age 14 and reported in parentheses.

$* * * ; * * ; *$ statistically significant at the $1 \% ; 5 \% ; 10 \%$ level. 
Appendix Table C. Effect of leaving school in an economic downturn on self-esteem: Instrumental variable models with alternative controls for individual heterogeneity

\begin{tabular}{lcc}
\hline \hline Year in which self-esteem is measured & $\mathbf{1 9 8 7}$ & $\mathbf{2 0 0 6}$ \\
\hline Men & & 52.87 \\
\hline Sample mean & 55.29 & $-2.1333^{* * *}$ \\
\hline Core model & 1.1637 & $(0.7335)$ \\
& $(1.1152)$ & $-2.2203 * * *$ \\
Long model $^{1}$ & 1.1219 & $(0.7015)$ \\
\hline $\mathrm{N}$ & $(1.1408)$ & 2,817 \\
\hline Women & 2,817 & 49.42 \\
\hline Sample mean & & -0.8836 \\
\hline Core model $^{-1}$ & 50.82 & $(1.7617)$ \\
\hline Long model $^{1}$ & 1.1740 & -1.0806 \\
\hline $\mathrm{N}$ & $(1.7123)$ & $(1.7356)$ \\
\hline
\end{tabular}

Notes: NLSY79 sample weights applied. All models adjust for personal characteristics, and school-leaving state and year fixed effects. Standard errors are clustered around the age 14 state of residence and reported in parentheses in all regressions.

${ }^{1}$ The long model includes controls for urbancity, a language other than English spoken in the home, and access to cultural materials (library cards, newspapers, and magazines) at age 14.

$* * * ; * * * *$ statistically significant at the $1 \% ; 5 \% ; 10 \%$ level. 
Appendix Table D. Effect of leaving school in an economic downturn on self-esteem: Instrumental variable models with unbalanced panel

\begin{tabular}{lcc}
\hline Year in which self-esteem is measured & $\mathbf{1 9 8 7}$ & $\mathbf{2 0 0 6}$ \\
\hline Men & 55.29 & 52.87 \\
\hline Sample mean & 1.1637 & $-2.1333^{* * *}$ \\
\hline Balanced panel & $(1.1152)$ & $(0.7335)$ \\
\hline $\mathrm{N}$ & 2,817 & 2,817 \\
\hline Sample mean & 54.57 & 52.54 \\
\hline Unbalanced panel & 0.6784 & $-1.8045^{* *}$ \\
& $(0.5652)$ & $(0.6814)$ \\
\hline $\mathrm{N}$ & 3,539 & 2,970 \\
\hline Sample mean & & 49.42 \\
\hline Balanced panel & 50.82 & -0.8836 \\
& 1.1740 & $(1.7617)$ \\
\hline Sample mean & $(1.7123)$ & 3,090 \\
\hline Unbalanced panel & 3,090 & 49.49 \\
\hline $\mathrm{N}$ & 51.03 & -0.7719 \\
\hline Notes: NLSY7 & 0.1935 & $(0.5442)$ \\
\hline
\end{tabular}

Notes: NLSY79 sample weights applied. All models adjust for personal characteristics, and school-leaving state and year fixed effects. Standard errors are clustered around the age 14 state of residence and reported in parentheses in all regressions.

$* * * ; * * ; *=$ statistically significant at the $1 \% ; 5 \% ; 10 \%$ level. 


\section{References}

Acemoglu, D., Angrist, J., Bils, M., Rouse, C. E. (2001). "How large are human-capital externalities? Evidence from compulsory schooling laws." Nber Macroeconomics Annual 2000 15, 9-+

Almlund, M., Duckworth, A.L., Heckman, J., Kautz, T. (2011). Personality psychology and economics. IZA, Bonn, Germany

Altonji, J. G., Bharadwaj, P., Lange, F. (2012). "Changes in the Characteristics of American Youth: Implications for Adult Outcomes." Journal of Labor Economics 30, 783-828

Angrist, Joshua D., Pischke, J. (2009). Mostly Harmless Econometrics: An Empiricist's Companion. Princeton University Press, Princeton, NJ.

Bandura, A. (1978). "Self System in Reciprocal Determinism." American Psychologist 33, 344358

Becker, G. S. (1973). "Theory of Marriage .1." Journal of Political Economy 81, 813-846

Becker, Gary S. (1981). A treatise on the family. Harvard University Press, Cambridge, Mass.

Blascovich, J., Tomaka, J. (1991). Measures of self-esteem. In: Robinson J, Shaver P \& Wrightsman L (eds.) Measures of Personality and Social Psychological Attitudes. Academic Press, San Diego, CA, pp. 115-160.

Blau, Francine D., Kahn, Lawrence M. (2007). "Changes in the Labor supply behavior of married women: 1980-2000." Journal of Labor Economics 25, 393-438

Bound, John, Brown, Charles, Mathiowetz, Nancy. (2001). Chapter 59 Measurement error in survey data. In: Heckman JJ \& Leamer E (eds.) Handbook of Econometrics. Elsevier, pp. 3705-3843.

Brack, C. J., Orr, D. P., Ingersoll, G. (1988). "Pubertal Maturation and Adolescent Self-Esteem." Journal of Adolescent Health 9, 280-285

Bureau of Labor Statistics. (2013). The Employment Situation - April 2013. Statistics BoL (Ed.). Bureau of Labor Statistics, Washington, DC

Bureau of the Census. (1976). Statistical Abstract of the United States. In: Statistical Abstract of the United States. Bureau of the Census, Washington, DC

Chiteji, N. (2010). "Time Preference, Noncognitive Skills and Well Being across the Life Course: Do Noncognitive Skills Encourage Healthy Behavior?" American Economic Review 100, 200-204

Cooley, C.H. (1902). Human Nature and the Social Order. Charles Scribner's Sons, New York, NY.

Cunha, F., Heckman, J. J. (2008). "Formulating, Identifying and Estimating the Technology of Cognitive and Noncognitive Skill Formation." Journal of Human Resources 43, 738-782

Cunha, F., Heckman, J. J., Schennach, S. M. (2010). "Estimating the Technology of Cognitive and Noncognitive Skill Formation." Econometrica 78, 883-931

Festinger, Leon. (1954). "A Theory of Social Comparison Processes." Human Relations 7, 117140

Fletcher, J. M. (2013). "The effects of personality traits on adult labor market outcomes: Evidence from siblings." Journal of Economic Behavior \& Organization 89, 122-135

Gecas, V. (1982). "The Self-Concept." Annual Review of Sociology 8, 1-33

Gecas, V., Schwalbe, M. L. (1983). "Beyond the Looking-Glass Self - Social-Structure and Efficacy-Based Self-Esteem." Social Psychology Quarterly 46, 77-88

Genda, Yuji, Kondo, Ayako, Ohta, Souichi. (2010). "Long-Term Effects of a Recession at Labor Market Entry in Japan and the United States." Journal of Human Resources 45, 157-196

Haney, T. J. (2007). "'Broken windows" and Self-Esteem: Subjective understandings of 
neighborhood poverty and disorder." Social Science Research 36, 968-994

Heckman, J. J., Kautz, T. (2012). "Hard evidence on soft skills." Labour Economics 19, 451-464

Heckman, J. J., Rubinstein, Y. (2001). "The importance of noncognitive skills: Lessons from the GED testing program." American Economic Review 91, 145-149

Heckman, J. J., Stixrud, J., Urzua, S. (2006). "The effects of cognitive and noncognitive abilities on labor market outcomes and social behavior." Journal of Labor Economics 24, 411482

Heineck, G. (2011). "Does It Pay to Be Nice? Personality and Earnings in the United Kingdom." Industrial \& Labor Relations Review 64, 1020-1038

Hershbein, Brad J. (2012). Graduating High School in a Recession: Work, Education, and Home Production. In: The B.E. Journal of Economic Analysis \& Policy

James, W. (1893). The Principles of Psychology. Harvard University Press, Cambridge, MA.

Kahn, Lisa B. (2010). "The long-term labor market consequences of graduating from college in a bad economy." Labour Economics 17, 303-316

Kling, K. C., Hyde, J. S., Showers, C. J., Buswell, B. N. (1999). "Gender differences in selfesteem: A meta-analysis." Psychological Bulletin 125, 470-500

Kondo, Ayako. (2007). Differential effects of graduating during a recession across race and gender. In: Institute for Social and Economic Research and Policy Working Paper. Institute for Social and Economic Research and Policy, Essex, U.K.

Kwon, Illoong, Milgrom, Eva Meyersson, Hwang, Seiwoon. (2010). "Cohort Effects in Promotions and Wages." Journal of Human Resources 45, 772-808

MacDonald, Martha, Phipps, Shelley, Lethbridge, Lynn. (2005). "Taking Its Toll: The Influence of Paid and Unpaid Work on Women's Well-Being." Feminist Economics 11, 63-94

Maclean, J. C. (2014). "The lasting effects of leaving school in an economic downturn on alcohol use." Industrial and Labor Relations Review Accepted

Maclean, J. C., Covington, R., Sikora, A. (2013). Leaving school in an economic downturn: Long-run effects on marriage and fertility. University of Pennsylvania

Maclean, J.C. (2013). "The health effects of leaving school in a bad economy." J Health Econ $32,951-964$

Markowitz, F. E. (2001). "Modeling processes in recovery from mental illness: Relationships between symptoms, life satisfaction, and self-concept." Journal of Health and Social Behavior 42, 64-79

McLaughlin, Kenneth J., Bils, Mark. (2001). "Interindustry mobility and the cyclical upgrading of labor." Journal of Labor Economics 19, 94-135

Mead, G.H. (1934). Mind, Self, and Society. University of Chicago Press, Chicago, IL.

Mruk, C. (2006). Self-Esteem Research, Theory, and Practice: Toward a Positive Psychology of Self-Esteem. Springer, New York, NY.

Mueller, G., Plug, E. (2006). "Estimating the effect of personality on male and female earnings." Industrial \& Labor Relations Review 60, 3-22

National Bureau of Economic Research. (2010). U.S. Business cycle expansions and contractions. National Bureau of Economic Research, Cambridge, MA

Neumark, D. (2002). "Youth labor markets in the United States: Shopping around vs. staying put." Review of Economics and Statistics 84, 462-482

Okun, Arthur M. (1973). "Upward Mobility in a High-Pressure Economy." Brookings Papers on Economic Activity, 207-261

Oreopoulos, Philip, von Wachter, Till, Heisz, Andrew. (2012). "The Short- and Long-Term Career Effects of Graduating in a Recession." American Economic Journal: Applied Economics 4, 1-29 
Owens, T., King, A. (2001). Measuring Self-Esteem: Race, Ethnicity, and Gender Considered. In: Owens T, Stryker S \& Goodman N (eds.) Extending Self-Esteem Theory and Research. Cambridge University Press, New York: NY, pp. 56-84.

Oyer, Paul. (2006). "Initial Labor Market Conditions and Long-Term Outcomes for Economists." The Journal of Economic Perspectives 20, 143-160

Oyer, Paul. (2008). "The Making of an Investment Banker: Stock Market Shocks, Career Choice, and Lifetime Income." The Journal of Finance 63, 2601-2628

Porter, J. R., Washington, R. E. (1993). "Minority Identity and Self-Esteem." Annual Review of Sociology 19, 139-161

Reder, Melvin W. (1955). "The Theory of Occupational Wage Differentials." American Economic Review 45, 833-52

Rosenberg, M. (1965). Society and the adolescent self-image. Princeton University Press, Princeton, NJ.

Rosenberg, M. (1981). The Self-Concept: Social Product and Social Force. In: Rosenberg M \& Turner R (eds.) Social Psychology: Sociological Perspectives. Transaction Publishers, New Brunswick, NJ, pp. 593-624

Rosenberg, M., Pearlin, L. I. (1978). "Social-Class and Self-Esteem among Children and Adults." American Journal of Sociology 84, 53-77

Schoar, Antoinette, Zuo, Luo. (2011). Shaped by booms and busts: How the economy impacts CEO careers and management styles. In: NBER Working Paper Series. National Bureau of Economic Research, Cambridge, MA

Semeijn, J., Boone, C., van der Velden, R., van Witteloostuijn, A. (2005). "Graduates' personality characteristics and labor market entry an empirical study among dutch economics graduates." Economics of Education Review 24, 67-83

Stock, James H., Wright, Jonathan H., Yogo, Motohiro. (2002). "A Survey of Weak Instruments and Weak Identification in Generalized Method of Moments." Journal of Business \& Economic Statistics 20, 518-529

Twenge, J. M., Campbell, W. K. (2002). "Self-esteem and socioeconomic status: A meta-analytic review." Personality and Social Psychology Review 6, 59-71

Twenge, J. M., Crocker, J. (2002). "Race and self-esteem: Meta-analyses comparing Whites, Blacks, Hispanics, Asians, and American Indians and comment on Gray-Little and Hafdahl (2000)." Psychological Bulletin 128, 371-408

U.S. Census Bureau. (2012). Statistical Abstract of the United States 2012. In: Statistical Abstract of the United States U.S. Census Bureau, Washington, DC

Uriarte-Landa, Jorge, Hebert, Benoit-Paul. (2009). "Work-Life Balance of Older Workers." Perspectives on Labour and Income 21, 27-38

Waite, L. J., Luo, Y., Lewin, A. C. (2009). "Marital happiness and marital stability: Consequences for psychological well-being." Social Science Research 38, 201-212

Wood, J. V. (1989). "Theory and Research Concerning Social Comparisons of Personal Attributes." Psychological Bulletin 106, 231-248

Wozniak, A. (2010). "Are College Graduates More Responsive to Distant Labor Market Opportunities?" Journal of Human Resources 45, 944-970

Yang, Y. (2006). "How does functional disability affect depressive symptoms in late life? The role of perceived social support and psychological resources." Journal of Health and Social Behavior 47, 355-372 